\title{
Pengaruh Pengalaman, Etika Profesi, Objektivitas dan Time Deadline Pressure terhadap Kualitas Audit Di Badan Pengawas Keuangan dan Pembangunan Medan
}

\author{
Keumala Hayati ${ }^{1}$, Ester Marianita Pangaribuan², Munawarah³, Wenny \\ Anggeresia Ginting ${ }^{4}$
}

\author{
${ }_{1,2,3,4}$ Fakultas Ekonomi, Universitas Prima Indonesia
}

Email: keumalahayatihakim@gmail.com

Direvisi: 29 Mei 2019 Dipublikasikan: 30 Juni 2019

\begin{abstract}
Abstrak
Penelitian ini bertujuan untuk menganalisis dan memberikan bukti empiris Tentang: (1) Pengaruh Pengalaman auditor terhadap Kualitas Audit, (2) Pengaruh Etika Profesi auditor terhadap Kualitas Audit, (3) Pengaruh Objektivitas auditor terhadap Kualitas Audit, (4) Pengaruh Time Deadline Pressure auditor terhadap Kualitas Audit, (5) Pengaruh Pengalaman, Etika Profesi, Objektivitas dan Time Deadline Pressure secara bersamaan terhadap Kualitas Audit. Populasi dalam penelitian adalah seluruh auditor yang bekerja pada kantor BPKP Provinsi Sumatera Utara. Pengambilan sampel dilakukan dengan metode sampling jenuh, dengan jumlah sebanyak 95 responden dengan tingkat pengembalian sebesar 100\%. Teknik analisis data yang digunakan dalam penelitian ini analisis regresi linear berganda. Hasil penelitian pada hipotesis menujukkan bahwa (1) Pengalaman dan Etika Profesi berpengaruh positif dan signifikan terhadap Kualitas Audit, (2) Objektivitas dan Time Deadline Pressure tidak berpengaruh terhadap Kualitas Audit, dan (3) Pengalaman, Etika Profesi, Objektivitas, Dan Time Deadline Pressure secara bersamasama berpengaruh positif dan signifikan terhadap Kualitas Audit.
\end{abstract}

Kata Kunci : Pengalaman, Etika Profesi, Objektivitas, Time Deadline Pressure, Kualitas Audit

\begin{abstract}
Abstrak
The objective of the research was to analyze and provide physical evidence: (1) The effect of Experience of auditor on the Audit Qaulity (2) Effect of Professional Auditor Ethics on the Quality of Audit, (3) Effect of Auditor Objectivity on the Quality of Audit, 4) Effect of Auditor Time Deadline Pressure on the Quality Audit, (5) Effect of Experience, Professional Ethics, Objectivity And Time Deadline Pressure simultaneously on the Quality Audit. The research populations were all auditors working at BPKP office, North Sumatra Province. The research samples used were chosen using saturated sampling technique, consisting of 95 respondents with return rate of 100\%. The research data were analyzed using multiple regression analysis. Results of the analysis concluded that the (1) Experience and Professional Auditor Ethics significant positive effect on Audit Quality, (2) Objectivity and Time Deadline Pressure did not have any significant effect on Audit Quality, and (3) Experience, Ethics Profession, Objectivity, And Time Deadline Pressure simultaneously had a significant effect on Audit Quality.
\end{abstract}

Keywords: Experience, Ethic Professional,Objectivity, Time Deadline Pressure, AuditQuality 


\section{Pendahuluan}

Keumala Hayati

Dewasa ini, dunia berkembang sangat pesat termasuk di bidang perekonomian dan dunia usaha. Perkembangan perekonomian dan dunia usaha yang semakin pesat saat ini dipengaruhi dengan adanya perkembangan dalam teknologi informasi dan komunikasi. Seiring dengan perkembangan ekonomi yang pesat, pertumbuhan perusahaan dan berbagai bentuk badan hukum perusahaan di suatu negara menimbulkan perkembangan profesi akuntan publik. Profesi akuntan publik bertanggungjawab untuk menaikkan tingkat keandalan laporan keuangan perusahaan, sehingga masyarakat memperoleh informasi keuangan yang andal sebagai dasar pengambilan keputusan. Adanya kebutuhan akan laporan keuangan yang memadai dan dapat dipertanggungjawabkan membawa banyak perusahaan bergantung pada jasa audit yang ditawarkan oleh auditor. Guna menunjang profesionalismenya, auditor dalam melaksanakan tugas auditnya harus berpedoman pada standar audit yang ditetapkan oleh Ikatan Akuntansi Indonesia (IAI), yakni standar umum, standar pekerjaan lapangan dan standar pelaporan. Standar umum merupakan cerminan kualitas pribadi yang harus dimiliki oleh seorang auditor yang mengharuskan auditor untuk memiliki keahlian dan pelatihan teknis yang cukup dalam melaksanakan prosedur audit. Auditor harus dapat mematuhi standar profesi dan teknis yang terdapat didalam Standar Profesional Akuntan Publik (SPAP).

Kualitas audit yang dihasilkan oleh suatu Kantor Akuntan Publik atau Badan Pengawasan Keuangan dan Pembangunan dipengaruhi oleh kualitas dan kinerja yang dimiliki oleh auditor yang tergabung didalam Kantor Akuntan Publik atau Badan Pengawasan Keuangan dan Pembangunan tersebut. Terdapat beberapa faktor yang dapat mempengaruhi kualitas dan kinerja dari auditor itu sendiri. Pengalaman seorang auditor sangat berperan penting dalam meningkatkan keahlian sebagai perluasan dari pendidikan formal yang telah diperoleh auditor. Sesuai dengan standar umum dalam Standar Profesional Akuntan Publik bahwa auditor disyaratkan memiliki pengalaman kerja yang cukup dalam profesi yang ditekuninya, serta dituntut untuk memenuhi kualifikasi teknis dan berpengalaman dalam bidang industri yang digeluti kliennya. Pengalaman auditor akan terus meningkat seiring dengan makin banyaknya audit yang dilakukan serta kompleksitas transaksi keuangan perusahaan yang di audit sehingga akan menambah dan memperluas pengetahuannya di bidang akuntansi dan auditing.

Menjunjung tinggi aturan etika profesi dalam menjalankan tugas pemeriksaan sebagai auditor, juga merupakan salah satu faktor yang dapat mempengaruhi kualitas audit. Etika bertujuan membantu manusia untuk bertindak secara bebas tetapi dapat 
Sentralisasi volume 8 ( 2 ) Hal : 67- 76 | 2019 Pengaruh Pengalaman, Etika Profesi,Objektivitas... Doi (https://doi.org/10.33506/sl.v8i2.434) Keumala Hayati dipertanggungjawabkan. Dalam hal ini seorang auditor diharuskan memiliki etika yang baik dalam menjalankan tugasnya. Profesional dalam etika profesi mengisyaratkan suatu kebanggaan, komitmen pada kualitas, dedikasi pada kepentingan klien dan keinginan tulus dalam membantu permasalahan yang dihadapi klien sehingga profesi tersebut dapat menjadi kepercayaan masyarakat. Faktor lain dalam menentukan kualitas audit adalah objektivitas. Sikap seorang auditor untuk bisa memberikan penilaian yang objektif tanpa memihak siapapun. Penilaian tersebut berdasarkan Standar Keuangan dan Standar Profesional Akuntan Publik. Prinsip objektivitas mengharuskan anggota bersikap adil, tidak memihak, jujur secara intelektual, tidak berprasangka, serta bebas dari benturan kepentingan atau berada di bawah pengaruh pihak lain.

Penelitian ini bertujuan untuk mengetahui pengaruh pengalaman, etika profesi, objektivitas, dan time deadline pressure terhadap kualitas audit. Meskipun telah banyak penelitian mengenai kualitas audit, tetapi hasil penelitian tersebut beragam. Hal ini dikarenakan perbedaan periode penelitian maupun sampel penelitian dan sifat variabel yang diteliti. Penelitian ini dapat menambah rujukan penelitian yang berhubungan dengan kualitas audit.

\section{Metode Penelitian}

Penelitian ini dilakukan di Badan Pengawas Keuangan dan Pembangunan Medan .Metode Pendekatan yang dilakukan dalam penelitian ini adalah pendekatan kuantitatif.

\section{Teknik Analisis Data}

\section{Analisis Regresi Linear Berganda}

Analisis regresi linear berganda yang digunakan dalam penelitian ini memiliki model sebagai berikut:

$$
Y=a+b_{1} X_{1}+b_{2} X_{2}+b_{3} X_{3}+b_{4} X_{4}+e
$$

\section{Koefisien Determinasi}

Koefisien determinasi $\left(R^{2}\right)$ pada intinya mengukur seberapa jauh kemampuan model menerangkan variasi variabel dependen.

\section{Uji Hipotesis (Uji Signifikansi atau Uji t)}

Uji simultan atau disebut juga uji $\mathrm{F}$ dalam analisis regresi linear berganda bertujuan untuk mengetahui apakah variabel bebas (X) secara bersama-sama atau secara serempak (simultan) berpengaruh terhadap variabel terikat $(\mathrm{Y})$. 


\section{Uji Hipotesis Parsial}

Keumala Hayati

Uji parsial atau disebut juga uji t dalam analisis regresi linear berganda. uji statistik $\mathrm{t}$ pada dasarnya menunjukkan seberapa jauh pengaruh variabel penjelas atau independen secara individual dalam menerangkan variasi variabel dependen.

\section{Hasil dan Pembahasan}

Setelah dilakukan pengujian asumsi klasik yang meliputi uji normalitas, uji heteroskedastisitas, dan uji multikolinearitas, maka dilakukan regresi linear berganda. Berikut tabel hasil regresi linear berganda:

\begin{tabular}{|c|c|c|c|c|c|c|}
\hline \multicolumn{7}{|c|}{ Coefficients $^{a}$} \\
\hline \multirow[b]{2}{*}{ Model } & & \multicolumn{2}{|c|}{$\begin{array}{c}\text { Unstandardized } \\
\text { Coefficients }\end{array}$} & \multirow{2}{*}{$\begin{array}{c}\text { Standardized } \\
\text { Coefficients } \\
\text { Beta } \\
\end{array}$} & \multirow[b]{2}{*}{$\mathbf{t}$} & \multirow[b]{2}{*}{ Sig. } \\
\hline & & B & Std. Error & & & \\
\hline \multirow[t]{5}{*}{1} & (Constant) & -5.899 & 4.745 & & -1.243 & .217 \\
\hline & PEGALAMAN & .305 & .123 & .243 & 2.482 & .015 \\
\hline & ETIKA_PROFESI & .205 & .082 & .248 & 2.499 & .014 \\
\hline & OBJEKTIVITAS & -.198 & .227 & -.187 & -.873 & .385 \\
\hline & TIME_DEADLINE_PRESSURE & .418 & .239 & .376 & 1.748 & .084 \\
\hline
\end{tabular}

a. Dependent Variable: KUALITAS_AUDIT

Berdasarkan tabel diatas, maka diperoleh persamaan regresi linear berganda dalam penelitian ini dapat ditulis sebagai berikut:

Kualitas Audit $=-5,899$ Konstanta + 0,305 Pengalaman + 0,205 Etika Profesi - 0,198

\section{Objektivitas + 0,418 Time Deadline Pressure}

Dari persamaan tersebut dapat diperoleh keterangan sebagai berikut; 1) Nilai konstanta (a) adalah -5,899. Artinya jika variabel bebas yaitu pengalaman, etika profesi, objektivitas, time deadline pressure adalah konstan (nilai 0), maka nilai kualitas audit auditor pada kantor Badan Pengawasan Keuangan dan Pembangunan Provinsi Sumatera Utara akan mengalami penurunan sebesar $-5,899$ satuan. 2) Koefisien regresi Pengalaman (X1) adalah 0,305. Ini menunjukkan bahwa apabila pengalaman meningkat 1 satuan, maka kualitas audit auditor akan meningkat sebesar 0,305 satuan dengan syarat variabel bebas lainnya konstan. 3) Koefisien regresi Etika Profesi (X2) adalah 0,205. Ini menunjukkan bahwa apabila etika profesi meningkat 1 satuan, maka kualitas audit auditor akan meningkat sebesar 0,205 satuan dengan syarat variabel bebas lainnya konstan. 4) Koefisien regresi Objektivitas (X3) adalah -0,198. Ini menunjukkan bahwa apabila objektivitas meningkat 1 satuan, maka kualitas audit auditor akan menurun sebesar 0,198 satuan dengan syarat variabel bebas lainnya konstan. 5) Koefisien 
Sentralisasi volume 8 ( 2 ) Hal : 67- 76 | 2019

Pengaruh Pengalaman, Etika Profesi,Objektivitas...

Doi (https://doi.org/10.33506/sl.v8i2.434)

Keumala Hayati

regresi time deadline pressure (X4) adalah 0,418. Ini menunjukkan bahwa apabila time deadline presuure meningkat 1 satuan, maka kualitas audit auditor akan meningkat sebesar 0,418 satuan dengan syarat variabel bebas lainnya konstan.

\section{Koefisien Determinasi}

\begin{tabular}{|c|c|c|c|c|}
\hline \multicolumn{5}{|c|}{ Model Summary ${ }^{b}$} \\
\hline Model & $\mathbf{R}$ & R Square & Adjusted R Square & Std. Error of the Estimate \\
\hline 1 & $.430^{\mathrm{a}}$ & .185 & .149 & 1.868 \\
\hline
\end{tabular}

Berdasarkan tabel Model Summary, diketahui nilai koefisien determinasi hipotesis adalah 0,149. Hal ini menunjukkan bahwa 14,9 \% variasi variabel kualitas audit (Y) dapat dijelaskan oleh variasi variabel pengalaman (X1), etika profesi (X2), objektivitas (X3), dan time deadline pressure (X4). Sisanya $85,1 \%$ merupakan variabel lain yang tidak diteliti dalam penelitian ini.

\section{Pengalaman Terhadap Kualitas Audit}

Hasil pengujian statistik parsial sebagai berikut: Variabel Pengalaman mempunyai nilai signifikan $0,015<0,05$ dan hasil $t_{\text {hitung }}>t_{\text {tabel }}(2,482>1,98667)$ maka $\mathrm{H}_{0}$ ditolak dan $\mathrm{H}_{\mathrm{a}}$ diterima, yang berarti bahwa variabel Pengalaman secara parsial berpengaruh positif dan signifikan terhadap Kualitas Audit pada kantor Badan Pengawasan Keuangan dan Pembangunan Provinsi Sumatera Utara. Hasil penelitian ini sejalan dengan penelitian terdahulu seperti penelitian Syahmina dan Suryono (2016) tentang "Pengaruh Pengalaman, Etik Profesi, Objektivitas dan Time Deadline Pressure Terhadap Kualitas Audit" (Studi pada KAP di kota Surabaya) yang menyatakan bahwa pengalaman berpengaruh positif dan signifikan terhadap kualitas audit, sehingga semakin tinggi pengalaman yang dimiliki seorang auditor semakin baik pula kualitas audit yang dilakukan.

\section{Pengaruh Etika Profesi Terhadap Kualitas Audit}

Dari hasil penelitian $t_{\text {hitung }}$ dan $t_{\text {tabel }}$ yang diperoleh bahwa etika profesi secara parsial berpengaruh positif dan signifikan terhadap kualitas audit pada kantor Badan Pengawasan Keuangan dan Pembangunan Provinsi Sumatera Utara. Hasil penelitian berdasarkan $t_{\text {hitung }}>\quad t_{\text {tabel }} \quad(2,499>1,98667)$ dengan nilai signifikan 0,014 . Bahwa etika 
Sentralisasi volume 8 ( 2 ) Hal : 67- 76 | 2019 Pengaruh Pengalaman, Etika Profesi,Objektivitas... Doi (https://doi.org/10.33506/sl.v8i2.434) Keumala Hayati profesi berpengaruh signifikan terhadap kualitas audit. Hasil penelitian ini sejalan dengan penelitian terdahulu seperti penelitian Wardana dan Ariyanto (2016) tentang "Pengaruh Gaya Kepemimpinan Transformasional, Objektivitas, Integritas dan Etika Auditor Terhadap Kualitas Audit" (Studi pada KAP di Denpasar) yang menyatakan bahwa etika auditor berpengaruh positif dan signifikan terhadap kualitas audit, sehingga semakin tinggi tingkat etika auditor akan meningkatkan kualitas audit yang dihasilkan auditor.

\section{Pengaruh Objektivitas Terhadap Kualitas Audit}

Dari hasil penelitian $t_{\text {hitung }}$ dan $t_{\text {tabel }}$ yang diperoleh bahwa objektivitas secara parsial tidak berpengaruh signifikan terhadap kualitas audit pada kantor Badan Pengawasan Keuangan dan Pembangunan Provinsi Sumatera Utara. Hasil penelitian berdasarkan $t_{\text {hitung }}<$ $\mathrm{t}_{\text {tabel }}(-873<1,98667)$ dengan nilai signifikan 0,385. Bahwa objektivitas tidak berpengaruh signifikan terhadap kualitas audit. Penelitian ini sejalan dengan penelitian Susilo dan Widyastuti (2015) tentang “ Integritas, Objektivitas, Profesionalisme Auditor dan Kualitas Audit di KAP Jakarta Selatan" yang menyatakan bahwa objektivitas tidak berpengaruh positif terhadap kualitas audit. Hal ini menunjukkan objektivitas seorang auditor dalam menjalankan tugasnya masih tidak memiliki pengaruh, mungkin saja seorang auditor masih terpengaruh terhadap kepentingan, atau pengaruh tekanan klien dalam menjalankan perannya dalam bertugas.

\section{Pengaruh Time Deadline Pressure Terhadap Kualitas Audit}

Dari hasil penelitian $\mathrm{t}_{\text {hitung }}$ dan $\mathrm{t}_{\text {tabel }}$ yang diperoleh bahwa time deadline pressure secara parsial tidak berpengaruh signifikan terhadap kualitas audit pada kantor Badan Pengawasan Keuangan dan Pembangunan Provinsi Sumatera Utara. Hasil penelitian berdasarkan $t_{\text {hitung }}<t_{\text {tabel }}$ $(1,748<1,98667)$ dengan nilai signifikan 0,084. Bahwa time deadline pressure berpengaruh signifikan terhadap kualitas audit. Hasil penelitian ini sejalan dengan penelitian Alfarizi (2016) tentang “Pengaruh Time Budget Pressure dan Time Deadline Pressure Terhadap Kualitas Audit pada BPKP Provinsi Sumatera Barat” yang menyatakan bahwa Time Deadline Pressure tidak berpengaruh terhadap kualitas audit. 
Sentralisasi volume 8 ( 2 ) Hal : 67- 76 | 2019 Pengaruh Pengalaman, Etika Profesi,Objektivitas...

Doi (https://doi.org/10.33506/sl.v8i2.434)

Keumala Hayati

Pengaruh Pengalaman, Etika Profesi, Objektivitas dan Time Deadline Pressure Terhadap Kualitas Audit

\begin{tabular}{llrrrrr}
\multicolumn{7}{c}{ ANOVA $^{\mathrm{b}}$} \\
\hline Model & & Sum of Squares & $\mathrm{df}$ & Mean Square & \multicolumn{1}{c}{$\mathrm{F}$} & Sig. \\
\hline 1 & Regression & 71.364 & 4 & 17.841 & 5.114 & $.001^{\mathrm{a}}$ \\
& Residual & 313.962 & 90 & 3.488 & & \\
& Total & 385.326 & 94 & & & \\
\hline
\end{tabular}

a. Predictors: (Constant), TIME_DEADLINE_PRESSURE, ETIKA_PROFESI, PEGALAMAN, OBJEKTIVITAS

b. Dependent Variable: KUALITAS_AUDIT

Berdasarkan tabel diatas, hasil penelitian ini membuktikan secara simultan variabel Pengalaman, Etika Profesi, Objektivitas dan Time Deadline Pressure secara simultan berpengaruh terhadap Kualitas Audit pada kantor BPKP Provinsi Sumatera Utara. Penelitian ini sejalan dengan penelitian Syahmina dan Suryono (2016) tentang "Pengaruh Pengalaman, Etik Profesi, Objektivitas dan Time Deadline Pressure Terhadap Kualitas Audit" (Studi pada KAP di kota Surabaya) yang menyatakan bahwa pengalaman, etika profesi, objektivitas dan time deadline pressure secara simultan berpengaruh positif terhadap kualitas audit.

Adapun pembahasan sebelumnya dalam penelitian ini diketahui bahwa variabel objektivitas dan time deadline pressure tidak berpengaruh positif dan tidak signifikan secara parsial oleh masing- masing variabel terhadap kualitas audit pada kantor BPKP Provinsi Sumatera Utara. Namun variabel pengalaman dan etika profesi secara parsial dapat berpengaruh positif dan signifikan dalam meningkatkan kualitas audit pada kantor BPKP Provinsi Sumatera Utara.

\section{Simpulan}

Dari hasil analisis yang dilakukan oleh peneliti, maka diperoleh kesimpulan sebagai berikut : 1) Pengalaman auditor secara parsial berpengaruh positif dan signifikan terhadap Kualitas Audit pada kantor Badan Pengawasan Keuangan dan Pembangunan Provinsi Sumatera Utara. 2) Etika Profesi auditor secara parsial berpengaruh positif dan signifikan terhadap Kualitas Audit pada kantor Badan Pengawasan Keuangan dan Pembangunan Provinsi Sumatera Utara. 3) Objektivitas auditor secara parsial tidak berpengaruh positif dan tidak signifikan terhadap Kualitas Audit pada kantor Badan Pengawasan Keuangan dan Pembangunan Provinsi Sumatera Utara. 4) Time Deadline Pressure auditor secara parsial tidak berpengaruh positif dan tidak signifikan terhadap Kualitas Audit pada kantor Badan Pengawasan Keuangan dan 
Sentralisasi volume 8 ( 2 ) Hal : 67- $76 \mid 2019$

Pengaruh Pengalaman, Etika Profesi,Objektivitas...

Doi (https://doi.org/10.33506/sl.v8i2.434)

Keumala Hayati

Pembangunan Provinsi Sumatera Utara. 5) Pengalaman, Etika Profesi, Objektivitas dan Time

Deadline Pressure secara simultan berpengaruh signifikan terhadap Kualitas Audit pada kantor Badan Pengawasan Keuangan dan Pembangunan Provinsi Sumatera Utara.

\section{Daftar Pustaka}

Agoes, Sukrisno \& I Cenik Ardana. 2014. Etika Bisnis dan Profesi. Ed. Revisi, Jakarta: Salemba Empat.

Alfarizi, Novrian. 2016. Pengaruh Time Budget Pressure dan Time Deadline Pressure Terhadap Kualitas Audit. Skripsi. Universitas Andalas. Padang.

Alfiati, Rifka. 2017. Pengaruh Etika Auditor, Skeptisme Profesional dan Kompetensi Auditor Terhadap Kualitas Audit. Artikel. Universitas Negeri Padang. Sumatera Barat.

Anshori, Muslich \& Sri Iswati. 2009. Metodologi Penelitian Kuantitatif. Surabaya: Airlangga University Press (AUP).

Asih, Dwi Ananing Tyas. 2006. Pengaruh Pengalaman terhadap Peningkatan Keahlian Auditor dalam Bidang Auditing. Skripsi. Universitas Islam Indonesia. Yogyakarta.

Ayuningtyas, H. A. 2012. Pengaruh Pegalaman Kerja, Independensi, Obyektifitas, Integritas dan Kompetensi terhadap Kualitas Hasil Audit. Skripsi. Universitas Diponegoro. Semarang.

Badjuri, Achmad. 2011. Faktor- Faktor yang Berpengaruh Terhadap Kualitas Audit Auditor Independen. Jurnal Dinamika Keuangan dan Perbankan. Vol. 3. No. 2. Universitas Stikubank. Semarang.

Dewi, Ajeng Citra. 2016. Pengaruh Pegalaman Kerja, Kompetensi, dan Independens terhadap Kualitas Audit dengan Etika Auditor Sebagai Variabel Moderasi (Studi Empiris pada Auditor Internal Inspektorat Provinsi Daerah Istimewa Yogyakarta) Skripsi.Universitas Negeri Yogyakarta. Yogyakarta.

Elder, R. J. et.al. 2013. Jasa Audit dan Assurance. Jakarta: Salemba Empat.

Ghozali, Imam. 2016. Aplikasi Analisis Multivariate dengan Program IBM SPSS 23. Ed. 8. Semarang: Badan Penerbit Universitas Diponegoro.

Harjanto. 2014. Pengaruh Kompetensi, Independensi, Objektivitas, Akuntabilitas dan Integritas terhadap Kualitas Audit dengan Etika Auditor sebagai Variabel Moderasi (Studi Empiris KAP di Semarang). Skripsi . Universitas Diponegoro Semarang.

Institut Akuntan Publik Indonesia. 2008. Kode Etik Profesi Akuntan Publik. Jakarta: Dewan Standar Profesional Akuntan Publik.

Kurnia. 2011. Pengaruh tekanan Waktu Audit dan Locus of Control terhadap Tindakan 


\section{Sentralisasi volume 8 ( 2 ) Hal : 67- $76 \mid 2019$}

Pengaruh Pengalaman, Etika

Profesi,Objektivitas...

Doi (https://doi.org/10.33506/sl.v8i2.434)

Keumala Hayati

yang Menurunkan Kualitas Audit. Jurnal Ekuitas 15(4):456-476

Kusuma, N. F. B. A. 2012. Pengaruh Profesionalisme Auditor, Etika Profesi dan Pengalaman Auditor terhadap Tingkat Pertimbangan Materialitas. Skripsi. Universitas Negeri Yogyakarta.

Kushasyandita, Sabhrina. 2012. Pengaruh Pengalaman, Keahlian, Situasi Audit, Etika, dan Gender terhadap Ketepatan Pemberian Opini Auditor melalui Skeptisisme Profesional Auditor (Studi Kasus pada KAP Big Four di Jakarta). Skripsi. Fakultas Ekonomika dan Bisnis Universitas Diponegoro. Semarang.

Lautina, Maya Fenriyanti. 2011. Pengaruh Time Budget Pressure, Locus Of Control dan Perilaku Disfungsional Audit terhadap Kinerja Auditor (Studi Pada Kantor Akuntan Publik Indonesia). Jurnal Telaah \& Riset Akuntansi. Vol. 4. No. 1. Universitas Syiah Kuala. Aceh.

Lestari, Riski Oktavia. 2013. Pengaruh Time Budget Pressure, Time Deadline Pressure, dan Exercised Responsibility terhadap Kinerja Auditor. Skripsi. Universitas Negeri Surabaya. Surabaya.

Parasayu, Annisa \& Abdul Rohman. 2014. Analisis Faktor-Faktor Yang Mempengaruhi Kualitas Hasil Audit Internal (Studi Persepsi Aparat Intern Pemerintah Kota Surakarta dan Kabupaten Boyolali). Diponegoro Journal Of Accounting. Vol. 3. No. 2. Universitas Diponegoro. Semarang.

Ramadhayanti, Rezki Wulan. 2013. Pengaruh Pengalaman, Otonomi, Profesionalisme dan Ambiguitas Peran terhadap Kinerja Auditor. Skripsi. Universitas Negeri Yogyakarta, Daerah Istimewa Yogyakarta.

Rosnidah, Ida Rawi \& Kamarudin. 2010. Analisis Dampak Motivasi dan Profesionalisme terhadap Kualitas Audit Aparat Inspektorat dalam Pengawasan Keuangan Daerah (Studi Empiris Pada Pemerintahan Kabupaten Cirebon). Jurnal Akuntansi. Bandung.

Sari, Nungky Nurmalita. 2011. Pengaruh Pengalaman Kerja, Independensi, Objektivitas, Integritas, Kompetensi dan Etika terhadap Kualitas Audit. Skripsi. Universitas Diponegoro, Semarang.

Singgih, Muliani. Elisha \& Icuk Rangga Bawono. 2010. Pengaruh Independensi, Pengalaman, Due Professional Care, dan Kuntabilitas terhadap Kualitas Audit (Studi Empiris pada KAP Big Four di Indonesia). Simposium Nasional Akuntansi XIII Puwokerto. Universitas Jenderal Soedirman. Semarang.

Sugiyono. 2008. Metode Penelitian Bisnis. Bandung: CV Alfabeta.

Sugeng, Pamudji \& Harvita Y. Ayuningtyas. 2012. Pengaruh Pengalaman Kerja, Independensi, Objektivitas, dan Kompetensi Terhadap Kualitas Hasil Audit (Studi Kasus Pada Auditor Inspektorat Kota/Kabupaten di Jawa Tengah). Diponegoro 


\section{Sentralisasi volume 8 ( 2 ) Hal : 67- $76 \mid 2019$ \\ Pengaruh Pengalaman, Etika \\ Profesi,Objektivitas... \\ Doi (https://doi.org/10.33506/sl.v8i2.434) \\ Keumala Hayati}

Journal Of Accounting. Universitas Diponegoro. Semarang.

Sujarweni, V. Wiratna . 2015. SPSS Untuk Penelitian. Yogyakarta: Pustaka Baru Press.

Sukriah, I.A \& B.A. Inapty. 2009.Pengaruh Pengalaman Kerja, Independensi, Objektivitas, Integritas, dan Kompetensi terhadap Kualitas Hasil Pemeriksaan. Simposium Nasional Akuntansi XII. Palembang.

Susilo, A. P \& Tri Widyastuti. 2015. Integritas, Objektivitas, Profesionalisme Auditor dan Kualitas Audit. Jurnal Riset Akuntansi dan Perpajakan. Vol. 2. No. 1. Universitas Pancasila. Jakarta Selatan.

Syahmina, Fidzah \& Bambang Suryono. 2016. Pengaruh Pengalaman, Etik Profesi, Objektifitas dan Time Deadline Pressure terhadap Kualitas Audit. Jurnal Imu dan Riset Akuntansi. Vol. 5. No. 4. Sekolah Tinggi Ilmu Ekonomi Indonesia (STIESA). Surabaya.

Syaravina, Lia Edli. 2015. Pengaruh Profesionalisme, Etika Profesi, Pengalaman Auditor dan Independensi terhadap Pertimbangan Tingkat Materialitas (Studi Empiris BPKP RI Perwakilan Provinsi Riau). Jom FEKON. Vol. 2. No.1. Fakultas Ekonomi Universitas Riau. Pekanbaru.

Tandiontong, Mathius. 2016. Kualitas Audit dan Pengukurannya. Bandung: CV Alfabeta.

Wardana, Made Aris \& Dodik Ariyanto. 2016. Pengaruh Gaya Kepemimpinan Transformasional, Objektivitas, Integritas dan Etika Auditor terhadap Kualitas Audit.E-Jurnal Akuntansi Universitas Udayana. Bali. 